\title{
The Effect of Working Capital Management on Dividend Policy: An Empirical Analysis of Listed Firms in Ghana
}

\author{
Ibrahim Nandon Yakubu', * \\ 'Department of Banking and Finance, Ankara Yildirim Beyazit University, Turkey
}

ABSTRACT - Relying on more recent data spanning 2007-2016, this paper investigates the impact of working capital management (WCM) on dividend policy of listed non-financial firms in Ghana. Specifically, the study assesses the effect of cash conversion cycle (CCC), days inventory outstanding (DIO), profitability, and firm growth on dividend policy. Employing the ordinary least squares (OLS) analytical technique, the findings reported that working capital management (in terms of cash conversion cycle and days inventory outstanding) and dividend policy are positively related, with DIO having a significant effect on dividend policy. The results also established a positive association between the control variables (profitability and firm growth) and dividend policy albeit insignificantly. Based on the findings, the study concludes that working capital management in terms of days inventory outstanding (DIO) is a critical factor influencing firms' dividend policy decisions. The study extends the inconclusive empirical evidence on the determinants of dividend policy and fills the lacuna in existing literature by focusing on how working capital management practices influence dividend policy of firms in Ghana. The findings are also useful to the board of directors of non-financial firms in deciding an appropriate dividend policy, and to the shareholders in making investment decisions.

ARTICLE HISTORY
Received: 13-11-2020
Accepted: 05-01-2021

KEYWORDS

Dividend policy

Working capital

Profitability

Ghana

\section{INTRODUCTION}

Dividend policy has been an area of debate in the corporate finance literature. It is a fundamental issue in finance due to its significant impact on investment and firm financing decisions. Dividend refers to the shareholders' return on the money invested in the acquisition of a given company's stock. According to Westerfield and Jordan (2007), dividend policy aims to maximize the returns of shareholders, including dividends and capital gains. For this reason, most companies are interested in how much of their earnings or profits should be paid to shareholders as well as the amount to be retained for further investment. Hence, an optimal dividend decision is essential.

In addition to the series of theoretical models on dividend policy, several empirical studies over the years have thoroughly examined the factors inducing dividend payment policy in both developed and developing countries (see Ho, 2003; Amidu \& Abor, 2006; Al-Kuwari, 2009; Gill et al., 2010; Ramli, 2010; Imran, 2011; Hashemi \& Zadeh, 2012; Agyemang Badu, 2013; Malik et al., 2013; Bushuru et al., 2015; Yusof \& Ismail, 2016; Olarewaju et al., 2019; Yakubu, 2019). The evidence reported, however, remains inconclusive.

In determining the dividend payment decisions of firms, a number of market and firm characteristics (such as profitability, liquidity, firm size, growth, investment opportunities, etc.) are commonly used as potential variables influencing dividend policy decisions. A crucial factor that has received less attention in the dividend policy determinants literature is working capital management. Working capital management involves a firm's ability to efficiently manage its current assets and liabilities in a way that provides maximum returns on assets and for its shareholders (Makori \& Jagongo, 2013; Yakubu et al., 2017). Efficient working capital management can lead to high profits and dividends. While few studies have been carried out on working capital management and dividend policy relationship in other countries (Oladipupo \& Ibadin, 2013 in Nigeria; Bushuru et al., 2015; Olang \& Grace, 2017 in Kenya), the effect of working capital management on firms' dividend policy decisions with specific reference to Ghana has not yet been investigated. This paper thus seeks to address the literature gap by examining the impact of working capital management on dividend policy of firms in Ghana using listed non-financial firms. The study will extend the existing empirical evidence on dividend policy determinants. The findings are also useful to the board of directors of non-financial firms in deciding an appropriate dividend policy, and to the shareholders in making investment decisions.

To gain more insight into this study, the paper has been structured as follows: The next section addresses the literature review while section 3 discusses the data and empirical strategy. In Section 4, empirical findings are presented. Section 5 concludes the study with some implications for policy. 


\section{LITERATURE REVIEW}

At the theoretical front, several theories have been propounded to explain dividend policy. One of the earliest dividend policy theories is the Modigliani \& Miller Theory by Miller and Modigliani in 1961. The theory suggests that the dividend policy of a firm has no impact on its value. Investors' rationality, market efficiency, no taxes and bankruptcy costs, the absence of agency cost and symmetric information availability are the basic underlining assumptions of this theory. A major implication of this theory is that the investment policy of a firm is independent of the dividend policy. However, the bird-in-hand theory of dividend policy suggests that there is a link between the value of firms and payouts for dividends (Lintner, 1956). The theory postulates that dividends are less risky, as they become more certain than capital gains. As a result, investors would prefer dividends from stocks to capital gains. Also, the signaling theory is another important theory that explains dividend policy. In contrast to the assumption of symmetrical information by the Modigliani \& Miller proposition, the signaling theory posits that management of a firm has more accurate information than external investors about the firm's future decisions on investments, future income, and profitability. Managers may therefore decide the dividend level to provide the inventors with this internal information (Bhattacharya, 1979). The intuition behind this argument is based on the irregularity of information between managers and external investors. Consequently, dividend policy is relevant under this model (Al-Kuwari, 2009). In addition to these theories, is the agency cost theory by Jensen and Meckling (1976), which explains that the dividend policy of firms is determined by agency costs arising from the divergence of ownership and control. The theory emphasizes on cost reduction mechanisms due to principal-agent problems. It suggests that dividend payment can possibly help reduce the agency costs related to factors such as firm growth, free cash flows, debt financing, investment opportunities, firm size, large shareholders and risks (Utami \& Inanga, 2011).

Empirically, extensive studies have been carried out to examine what factors drive firms to pay dividends. For instance, Kania and Bacon (2005) assessed the impact of profitability, growth, risk, liquidity, and expansion on the dividend policy of firms listed on NASDAQ, AMEX, NYSE, and OTC exchanges with a sample of 542 firms. Using OLS analytical technique, the study concluded that dividend payout ratio is significantly affected by profitability, growth, risk, and liquidity.

In India, Anil and Kapoor (2008) analyzed the factors influencing the dividend payout policy of Indian Information Technology sector for a period of seven years (2000-2006). Evidence from their study revealed that the dividend payout policy of Indian Technology sector is driven by liquidity and earnings variability while corporate tax, cash flows, growth in sales do not influence dividend policy.

Zhuang (2008) in the quest to establish the determinants of dividend policy of firms in the United Kingdom (UK) used a static panel data model with dataset spanning 1990 to 2007. Evidence from the OLS regression showed that dividend policy of listed UK firms is motivated by market capitalization. Return on assets, earning per share, market-tobook ratio, debt-equity ratio, and tax insignificantly explain dividend policy.

Al-Kuwari (2009) used listed non-financial firms from the Gulf Co-operation Council (GCC) firms to establish the factors impacting on dividend policy. Applying the random effect technique, the study posited that profitability, firm size, and government ownership have a direct effect on dividend policy.

Chen and Dhiensiri (2009) analyzed the drivers of dividend policy of firms in New Zealand using listed firms in the New Zealand Stock Exchange (NZSE). They found that the dividend payout ratio of New Zealand firms is positively influenced by a firm's ownership dispersion. The study also revealed that dividend payout relates negatively to insider ownership and that firms with experience growth in revenues pay lower dividends.

Employing a sample of 320 non-financial firms listed in the Karachi Stock Exchange, Ahmed and Javid (2009) assessed the determinants of firms' dividend payout policy in Pakistan for the period 2001-2006. Relying on the Lintner (1956) model and applying the Generalized Method of Moments (GMM) as estimation technique, the findings revealed that profitability of firms, liquidity, firm size, and market concentration, and ownership concentration drive divided policy payouts.

In Ghana, Marfo-Yiadom and Agyei (2011) employed a five-year panel data spanning 1999 - 2003 to assess the determinants of dividend policy of banks. Applying the fixed and random effects techniques, the regression results confirmed profitability, debt, changes in dividend and collateral capacity as significant variables influencing banks' dividend policy in Ghana.

Agyemang Badu (2013) assessed the dividend policy drivers of listed financial firms in Ghana for the period 2005 2009. The random and fixed effect techniques were applied to analyze the data obtained from the annual reports of the firms considered. The findings showed that firm age and liquidity enhance dividend payment as they depicted a positive significant relationship. However, profitability and collateral could not explain dividend payments.

Oladipupo and Ibadin (2013) in establishing the relationship between working capital management and dividend policy in Nigeria employed listed manufacturing companies with data covering 2002-2006. Using the ordinary least squares, the findings revealed that profitability and working capital management (in terms of net trade cycle) have a positive insignificant relationship with dividend policy while earnings and firm growth related negatively and insignificantly with dividend policy.

Bushuru et al. (2015) examined the impact of working capital management on dividend payout ratio in Kenya using data from listed firms on the Nairobi securities exchange for the period 2006-2013. The results from the multiple regression analysis established that working capital management (in terms of cash conversion cycle (CCC) and accounts payable period (APP)) have a significant positive relationship with dividend payout ratio. On the other hand, working 
capital management (in terms of accounts receivable collection period (ACP) and inventory collection period (ICP)) related negatively to dividend payout ratio though statistically significant. In Kenya also, Olang and Grace (2017) found that working capital management (measured by cash management, inventory management, and accounts receivables) has a positive and significant impact on firms' dividend payout policy.

Kaźmierska-Jóźwiak (2015) studied the factors motivating dividend payment of non-financial firms in Polish. Using a panel dataset covering 2000-2012, the results from the random effects estimation revealed that firms' profitability and leverage are negatively related to dividend policy though statistically significant.

Yusof and Ismail (2016) used 147 public listed companies in Malaysia to analyze the significant factors influencing dividend policy. Applying the fixed and random effects, pooled least squares model analytical techniques, the study reported earnings, debt, firm size, investment and firms with a large number of shareholders to have a significant effect on dividend payout policy.

From the extensive literature review, studies on the determinants of dividend policy have considered several factors (such as profitability, growth, corporate tax, liquidity, firm size, leverage, earnings, market concentration, ownership structure, etc.), with few examining the impact of working capital management on firms' dividend payout policy. In the context of Ghana, no study has been found linking the effect of working capital management and dividend payout policy. This paper thus seeks to address the literature gap by investigating the impact of working capital management on dividend policy of firms in Ghana using listed non-financial firms. The study will extend the existing empirical evidence on dividend policy determinants.

\section{METHODOLOGY}

\section{Sample Selection and Data Collection}

The sampling units for this research comprised of all non-financial firms listed on the Ghana Stock Exchange (GSE) for the period 2007-2016. A total of 20 firms were sampled. However, due to non-availability of data for some firms for the years considered, 11 firms were included in the study. Data were collected from the annual reports and financial statements of the selected firms.

\section{Description of Variables}

A number of variables including working capital management have been identified in the literature review as factors driving firms' dividend policy. This study included dividend per share as the dependent variable while cash conversion cycle and days inventory outstanding served as the independent variables. In addition, the study included profitability and firm growth as control variables which also impact significantly on firms' dividend policy. Table 1 outlines the description for each of the variables.

Table 1. Description of Variables

\begin{tabular}{lll}
\hline \multicolumn{1}{c}{ Variable } & Represented by & \multicolumn{1}{c}{ Proxy of Variable } \\
\hline Dividend Payout Policy & D & Dividend per share \\
\hline Cash Conversion Cycle & CCC & $\begin{array}{l}\text { Days Sales Outstanding plus Days of } \\
\text { Inventory Outstanding less Days } \\
\text { Payables Outstanding }\end{array}$ \\
\hline Days Inventory Outstanding & DIO & $\begin{array}{l}\text { Inventory/Cost of goods sold multiply by } \\
365\end{array}$ \\
\hline Profitability & ROA & Net Income/Total Assets \\
\hline Growth & GROW & Change in the natural log of sales \\
\hline
\end{tabular}

\section{Model Specification and Data Analysis}

The study follows the model used by Oladipupo and Ibadin (2013) and Yakubu (2016) with some modifications based on the selected variables. This is specified as follows:

$$
D_{i t}=\beta_{0}+\beta_{1} C C C_{i t}+\beta_{2} D_{I O}+\beta_{3} R O A_{i t}+\beta_{4} G R O W_{i t}+\varepsilon
$$

Where,

$D_{i t}=$ Dividend for firm $i$ in time $t$

$C C C_{i t}=$ Cash Conversion Cycle for firm $i$ in time $t$

$D I O_{i t}=$ Days Inventory Outstanding for firm $i$ in time $t$

$R O A_{i t}=$ Profitability for firm $i$ in time $t$

$G R O W_{i t}=$ Firm Growth for firm $i$ in time $t$ 
$\beta_{0}$ denotes the constant. $\beta_{1}$ to $\beta_{4}$ are the regression coefficients and $\varepsilon$ is the error term.

In establishing the relationship between dividend policy and the set of independent variables, the ordinary least square (OLS) estimations technique was employed. Given the quality of minimized bias and variance, OLS estimates are the most reliable regression estimates (Koutsoyiannis, 2003).

\section{FINDINGS AND DISCUSSIONS}

\section{Descriptive Statistics}

Table 2 shows the mean and standard deviation values of each variable used in this study. From the table, the average value of dividend policy is $\mathrm{GH} \phi 0.10$. With working capital management components, the average values for cash conversion cycle (CCC) and days inventory outstanding (DIO) are $-\mathbf{5 7 . 8 4}$ days and 148 days respectively. The negative value of CCC means that listed non-financial firms on average take less time to sell their inventory and receive cash from their customers. On the other hand, profitability and firm growth (natural log of sales) have an average mean distribution of -0.0005 and 0.011 respectively.

Table 2. Descriptive Statistics

\begin{tabular}{lrr}
\hline Variables & Mean & SD \\
\hline D & 0.102499 & 0.161826 \\
CCC & -57.838 & 934.1557 \\
DIO & 148.2214 & 112.0272 \\
ROA & -0.0005 & 0.368688 \\
GROW & 0.011359 & 0.011684 \\
\hline
\end{tabular}

\section{Correlation Analysis}

The correlation results in Table 3 show that dividend policy is positively correlated with all the independent variables except firm growth. The relationship however is not strong. Also, a weak correlation exists among the independent variables. The low correlation coefficients for the variables therefore justify the absence of multicollinearity in the analysis. However, the study further tested for multicollinearity using the variance inflation factor.

Table 3. Pairwise Correlation Matrix

\begin{tabular}{cccccc}
\hline Variables & D & CCC & DIO & ROA & GROW \\
\hline D & 1.0000 & & & & \\
CCC & 0.1254 & 1.0000 & & & \\
DIO & 0.3206 & 0.0429 & 1.0000 & & \\
ROA & 0.1284 & 0.3967 & -0.0198 & 1.0000 & \\
GROW & -0.0343 & 0.0470 & -0.0628 & -0.2229 & 1.0000 \\
\hline
\end{tabular}

\section{Test for Multicollinearity}

To further demonstrate that multicollinearity does not exist among the independent variables in the study, the Variance Inflation Factor (VIF) analysis was carried out as recommended by Gujarati (2003). In general, any VIF above 10 and a tolerance value below 0.10 is assumed to indicate a possible multicollinearity problem. Table 4 results however, show the absence of multicollinearity among the independent variables in this study. The values of VIF are all below 10 and the tolerance values are above 0.10 .

Table 4. Tolerance Value and Variance Inflation Factor

\begin{tabular}{lcc}
\hline Variables & \multicolumn{3}{c}{ Collinearity statistics } \\
\cline { 2 - 3 } & Tolerance & VIF \\
CCC & 0.819629 & 1.22 \\
DIO & 0.990424 & 1.01 \\
ROA & 0.781345 & 1.28 \\
GROW & 0.922854 & 1.08 \\
\hline
\end{tabular}

\section{Regression Analysis}

Table 5 shows the results of the regression analysis of the ordinary least squares model on the factors affecting dividend policy. 
Table 5. Regression Model Results

\begin{tabular}{lccc}
\hline Variable & Coefficient & t-statistic & Prob. \\
\hline CCC & 0.000012 & 0.673148 & 0.5023 \\
DIO & 0.000463 & 3.492242 & 0.0007 \\
ROA & 0.048031 & 1.059618 & 0.2917 \\
GROW & 0.097708 & 0.074240 & 0.9410 \\
C & 0.033506 & 1.129758 & 0.2612 \\
\hline R-square & 0.125028 & & \\
SE of Regression & 0.154229 & & \\
F-statistic & 3.750952 & & \\
Pro.(F-statistic) & 0.006815 & & \\
Observations & 110 & & \\
\hline
\end{tabular}

From the regression analysis the R-square value of 0.125 indicates that about $12.5 \%$ of the variations in dividend policy are explained by changes in cash conversion cycle (CCC), days inventory turnover (DIO), profitability (ROA) and firm growth (GROW). This means that other significant factors that are not considered in the model may account for $87.5 \%$ of the systematic changes in dividend policy. The regression model in overall is statistically significant $(F=3.751$, $p=0.0068$ ) which shows the fitness of the model. This also portrays that the factors considered in the model are crucial in explaining dividend policy.

The empirical findings show that there is a positive relationship between dividend policy and the working capital management variables (cash conversion cycle (CCC), days inventory turnover (DIO). However, only days inventory turnover (DIO) has a significant effect on dividend policy. The positive relationship between dividend policy and CCC means that non-financial firms are likely to pay more dividends when it takes them much time to generate cash. This result contradicts the CCC concept because firms with shorter CCC are healthier and profitable. Thus, firms taking lengthier time to generate cash may become insolvent especially for small firms which may affect their ability to pay dividends. The result, however, is consistent with the finding of Bushuru et al. (2015).

With days inventory outstanding (DIO), the positive coefficient indicates that the longer it takes non-financial firms to turn their inventories into sales, the more dividends they are likely to pay. This however, may not be the case, because if firms take a longer time to convert their inventories to sales, cash flows may be negatively affected hence lower profitability and dividend payment. The result therefore contrasts the notion that lesser DIO is better for firms.

Expectedly, the results show a positive relationship between profitability and dividend policy though statistically insignificant. That is, an increase in firms' profitability will also lead to a positive improvement in the firms' dividend payout ratio. The result of a positive relationship between profitability and dividend policy is similar to the findings by Owuigbe (2013) and Al-Najjar and Hussainey (2009). They asserted that highly profitable firms are capable of paying dividends compared to less profitable firms. This however, contrasts the argument by Amidu and Abor (2006) that profitability and dividend policy have a negative relationship.

The empirical findings further report that there is a positive insignificant relationship between firms' growth and dividend policy of listed non-financial firms, implying that firms with higher growth potentials tend to pay higher dividends as compared to lower growth firms. In line with this finding, Abdioğlu (2016) and Yusof and Ismail (2016) also established a positive association between dividend policy and firm growth.

\section{CONCLUSION AND RECOMMENDATIONS}

This study examined the relationship between working capital management and dividend policy of listed non-financial firms in Ghana. Estimates from the regression analysis showed that cash conversion cycle (CCC) and days inventory outstanding (DIO) (measures of working capital management) and dividend policy related positively, with DIO having a significant effect on dividend policy. The control variables (profitability and firm growth) and dividend policy also showed a positive association though insignificant. Based on the findings, the study concludes that working capital management in terms of days inventory outstanding (DIO) is a critical factor influencing firms' dividend policy decisions. Cash conversion cycle does not matter in dividend policy decisions of listed non-financial firms in Ghana. Therefore, in formulating and revising dividend policy, the board of directors must take into consideration a firm's days inventory outstanding (DIO). This study is not without limitations. It is based on small sample size and limited explanatory variables. For greater generalizability of the findings, future research may consider other non-financial firms with complete data that are not listed. Also, other working capital management components and firm-specific variables may be included as factors to determine dividend policy. Despite its limitations, the study extends the inconclusive empirical evidence on the determinants of dividend policy.

\section{REFERENCES}

Abdioğlu, N. (2016). On the Determinants of Corporate Dividend Policy: A Tobit Model Approach. Yönetim ve Ekonomi Araştırmaları Dergisi, 14(1), 332-345. 
Agyemang Badu, E. (2013). Determinants of dividend payout policy of listed financial institutions in Ghana. Research Journal of Finance and Accounting, 4(7), 185-190.

Ahmed, H., \& Javid, A. Y. (2008). The determinants of dividend policy in Pakistan. International Research Journal of Finance and Economics, 29, 110-125.

Al-Kuwari, D. (2009). Determinants of the dividend policy of companies listed on emerging stock exchanges: the case of the Gulf Cooperation Council (GCC) countries. Global Economy and Finance Journal, 2(2), 38-63.

Al-Najjar, B., \& Hussainey, K. (2009). The association between dividend payout and outside directorships. Journal of Applied Accounting Research, 10(1), 4-19.

Amidu, M., \& Abor, J. (2006). Determinants of dividend payout ratios in Ghana. The journal of risk finance, 7(2), 136145 .

Anil, K., \& Kapoor, S. (2008). Determinants of dividend payout ratios-a study of Indian information technology sector. International Research Journal of Finance and Economics, 15(1), 63-71.

Bhattacharya, S. (1979). Imperfect information, dividend policy, and "the bird in the hand" fallacy. Bell journal of economics, 10(1), 259-270.

Bushuru, R.W., Basweti, A.K., \& Mukonyi, P. M. (2015). The Relationship Between Working Capital Management and Divided Payout Ratio of Firms Listed in Nairobi Securities Exchange. International Journal of Economics, Commerce and Management, 3(11), 285-296.

Chen, J., \& Dhiensiri, N. (2009). Determinants of dividend policy: The evidence from New Zealand. International Research Journal of Finance and Economics, 34(34), 18-28.

Gill, A., Biger, N., \& Tibrewala, R. (2010). Determinants of dividend payout ratios: evidence from United States. The Open Business Journal, 3(1).

Gujarati, D. (2003). Basic Econometrics. Fourth Edition. Singapura: McGraw-Hill.

Hashemi, S. A., \& Zadeh, F. Z. F. (2012). The impact of financial leverage operating cash flow and size of company on the dividend policy (case study of Iran). Interdisciplinary Journal of Contemporary Research in Business, 3(10), 264-270.

Ho, H. (2003). Dividend policies in Australia and Japan. International Advances in Economic Research, 9(2), 91-100.

Imran, K. (2011). Determinants of dividend payout policy: A case of Pakistan engineering sector. The Romanian Economic Journal, 41(14), 47-59.

Jensen, M. C., \& Meckling, W. H. (1976). Theory of the firm: Managerial behavior, agency costs and ownership structure. Journal of financial economics, 3(4), 305-360.

Kania, SL., \& Bacon, F. W. (2005). What factors motivate the corporate dividend decision? ASBBS E-Journal, 1(1), 97107.

Kaźmierska-Jóźwiak, B. (2015). Determinants of dividend policy: evidence from polish listed companies. Procedia economics and finance, 23, 473-477.

Lintner, J. (1956). Distribution of incomes of corporations among dividends retained earnings and taxes". American Economic Review, 46(2), 97-113.

Makori, D. M., \& Jagongo, A. (2013). Working capital management and firm profitability: Empirical evidence from manufacturing and construction firms listed on Nairobi securities exchange, Kenya. International Journal of Accounting and Taxation, 1(1), 1-14.

Malik, F., Gul, S., Khan, M. T., Rehman, S. U., \& Khan, M. (2013). Factors influencing corporate dividend payout decisions of financial and non-financial firms. Research Journal of Finance and Accounting, 4(1), 35-46.

Marfo-Yiadom, E., \& Agyei, S. K. (2011). Determinants of dividend policy of banks in Ghana. International Research Journal of Finance and Economics, 61(61), 99-108.

Miller, M., \& Modigliani, F. (1961). Dividend policy, growth, and the valuation of shares. Journal of Business, 34(4), 411-433.

Oladipupo, A. O., \& Ibadin, P. O. (2013). Does working capital management matter in dividend policy decision? Empirical evidence from Nigeria. International Journal of Financial Research, 4(4), 140-145.

Olang, M. A., \& Grace, A. M. (2017). Effect of Working capital on the Dividend pay-out by firms firms listed at the Nairobi Securities Exchange, Kenya. International Journal of Finance and Banking Research, 3(2), 23-33.

Olarewaju, O. M., Migiro, S. O., \& Sibanda, M. (2019). Examining bank-specific determinants of the dividend payout ratio of Sub-Saharan Africa banks: the panel GMM approach. Afro-Asian Journal of Finance and Accounting, 9(1), 40-59.

Ramli, N. M. (2010). Ownership structure and dividend policy: Evidence from Malaysian companies. International Review of Business Research Papers, 6(1), 170-180.

Utami, S. R., \& Inanga, E. L. (2011). Agency costs of free cash flow, dividend policy, and leverage of firms in Indonesia. European Journal of Economics, Finance and Administrative Sciences, 33(6), 7-24.

Uwuigbe, O. R. (2013). Determinants of Dividend Policy: A study of selected listed Firms in Nigeria. Manager journal, 17, 107-119.

Westerfield, R., \& Jordan, B. D. (2007). Essentials of corporate finance. McGraw-Hill/Irwin.

Yakubu, I. N. (2016). Bank-Specific and Macroeconomic Determinants of Commercial Banks Profitability in Ghana. International Finance and Banking, 3(2), 89-99.

Yakubu, I. N. (2019). Revisiting the Factors Influencing Corporate Dividend Policy Decisions: Evidence from Listed Banks in Ghana. Management and Accounting Review (MAR), 18(3), 31-50. 
Yakubu, I. N., Alhassan, M. M., \& Fuseini, A. A. (2017). The Impact of Working Capital Management on Corporate Performance: Evidence from Listed Non-Financial Firms in Ghana. European Journal of Accounting, Auditing and Finance Research, 5(3), 68-75.

Yusof, Y., \& Ismail, S. (2016). Determinants of dividend policy of public listed companies in Malaysia. Review of International Business and Strategy, 26(1), 88-99.

Zhuang, L. (2008). Determinants of Corporate Dividend Policy in the UK market. Dissertation. University of Nottingham: United Kingdom.

\section{ACKNOWLEDGEMENT}

The author is grateful to the anonymous reviewers of this paper. 